\title{
Health-Related Physical Activity Report Card Applications: An Initial Examination of Physical Education Teachers' Views
}

\author{
Burhan PARSAK ${ }^{1 *}$ Leyla SARAÇ1 (D) \\ ${ }^{1}$ Department of Physical Education and Sports, Faculty of Sports Sciences, Mersin University, Mersin, Turkey
}

Keywords
Physical activity report
card,
Physical education,
Physical fitness,
Teacher

Article History
Received 13 August 2021
Revised 13 December 2021
Accepted 20 December 2021
Available Online 30 December 2021

* Corresponding Author: Burhan PARSAK

E-mail Address:

b.parsak@hotmail.com

\begin{abstract}
The purpose of this study was to reveal whether physical education teachers' views on health-related Physical Activity Report Card Applications differ according to gender and teaching experience variables. The participants were 33 female and 58 male teachers. The mean age of teachers was $36.96(\mathrm{SD} \pm 5.75)$, and the mean teaching experience was 10.74 (SD \pm 5.64). The Physical Activity Report Card Applications Assessment Scale [PARCAAS] was used to gather data. The results of the study revealed that the scores obtained from the subdimensions of "Enforcement", "Competence" and "Support" differed significantly between gender of teachers. It was also revealed that the scores obtained by female and male teachers in the sub-dimensions of "Applicability", "Impact" and "Difficulties" were similar. No significant differences were found in teaching experience on the scores obtained from the sub-dimensions of PARCAAS. Also, significant differences in "Enforcement", "Competence" and "Support" subdimensions were found; but no difference was found in "Applicability", "Impact", and "Difficulties" subdimensions between female and male physical education teachers. Both male and female physical education teachers had similar views on the "Applicability", "Impact," and "Difficulties" sub-dimensions of the PARCAAS, and it was concluded that they had difficulties during the report card application. Still, they thought that PARCAAS was applicable and practical. It was supposed that physical education teachers with teaching experience of 10 years or less and 11 years and above had difficulties applying for the report card, considered themselves moderately competent, received sufficient support, and thought that report card applications were applicable and practical.
\end{abstract}

Citation: Parsak, B., Saraç, L. (2021). Health-Related Physical Activity Report Card Applications: An Initial Examination of Physical Education Teachers' Views. Pamukkale Journal of Sport Sciences, 12(3), 21-40. doi.org/10.54141/psbd.982686 @ 2021 The Author(s) available online at https:// dergipark.org.tr/en/pub/psbd. This is an Open Access article distributed under the terms of the Creative Commons Attribution 4.0 International License, CC BY 4.0 (https://creativecommons.org/licenses/by/4.0/) 


\section{INTRODUCTION}

Lifestyles due to modernization, technological developments, and the fact that many jobs in daily life become easier make people less active day by day (Bulut, 2010). It has been reported that a significant part of the population in Turkey do not participate in regular physical activity (Ministry of National Health [MoNH], 2019a), and similarly, the physical activity levels of children and adolescents are low both in Turkey and in many countries (Doolan, 2012; Grasten et al., 2014; Kann et al., 2016). Studies have shown that low physical activity level is one of the most important risk factors for obesity (Altunkaynak \& Özbek, 2006; Biddle et al., 2004; Erdoğan et al., 2011; World Health Organization [WHO], 2018). The WHO (2021) reported that 1.9 billion people worldwide are overweight, and 650 million are obese. Studies have also revealed that overweight and obesity were seen in individuals in childhood and adolescence causes cardiovascular diseases, diabetes, musculoskeletal system disorders, psychosocial problems, school failure, and low self-esteem (Han et al., 2010; WHO, 2010).

It has been noted that the increasing prevalence of obesity among children and adolescents is becoming a concern for the future adult population (Edginton et al., 2010; Coşkun-Özyol \& Asma, 2020; Tremblay et al., 2014; WHO, 2021) and is also costing the health system a lot (Cechinni et al., 2010; Turkish Society of Endocrinology and Metabolism, 2018). Considering this threat, the acquisition of healthy living habits by societies has been one of the most important education and health policy priorities of many countries in recent years (Hacettepe University Faculty of Medicine, 2017; İnce \& Hünük, 2013; Ministry of National Education [MoNE], 2007; Tremblay et al., 2014). According to the statistics released by the Ministry of National Health (MoNH), it has been determined that $30 \%$ of children between the ages of 10-14 and approximately $21 \%$ of adolescents between the ages of 15-18 in Turkey are overweight and obese (MoNH, 2019b). It has also been reported by the MoNH (2014) that 55\% of children aged 12-14 and 58\% of adolescents aged 15-18 in Turkey do not engage in physical activity. It is emphasized that schools are ideal places to increase physical activity among children and youth. That school physical education is a lesson that significantly impacts increasing physical activity (Lonsdale et al., 2013).

The issue of health-related physical fitness has started to be discussed more within the scope of physical education lessons in many countries. An important place has been allocated to health-related physical fitness knowledge and practices under the "Active Participation and Healthy Life" learning area in Turkey's physical education curriculum updated in 2007 (İnce \& Hünük, 2013; MoNE, 2007). In this context, the Health-Related Physical Fitness Report Card 
Application was implemented for the first time in Turkey in the 2016-2017 academic year in cooperation with the MoNH and the MoNE to promote physical activity and to increase awareness of healthy nutrition and physical activity in students (MoNH/MoNE, 2017). Within the scope of this application, which was started to increase the knowledge level of the society within the scope of the fight against obesity, to ensure adequate and balanced nutrition and to gain regular physical activity habits, physical education teachers' were requested to measure the students' sit-ups, push-ups, sit and reach flexibility, body weight, and height twice a year (at the beginning and end of the academic year) (MoNE, 2018). Again, in this context, physical education and sports teachers are expected to increase student knowledge and competencies about health-related physical fitness parameters and prepare a learning environment suitable for students' needs (İnce \& Hünük, 2013). Studies show that it is not easy for physical education teachers to transition to a program that prioritizes health-related physical fitness goals (Castelli \& Williams, 2007; Haerens et al., 2011; İnce \& Hünük, 2013; Yılmaz, 2019).

In studies conducted on Physical Activity Report Card Applications; it has been revealed that physical education teachers have time, space, and material problems when making these physical fitness measurements. Teachers have difficulties in making measurements following the standards. It was stated that some of the teachers and school administrators believed that this practice would not benefit the students and the society in achieving the goals set for health-related physical fitness (Salman \& Sar1, 2020; Salman et al., 2018). In their study, Haerens et al. (2011) found that although many health-related programs were implemented in physical education and sports classes, physical education teachers were unsuccessful in implementing these programs, and they thought that they could not get enough support to increase their knowledge and skills. In studies examining the knowledge levels of physical education teachers and teacher candidates on health-related physical fitness, it was stated that health-related physical fitness knowledge level was insufficient (Ince \& Hünük, 2013; Santiago et al., 2016; Y1lmaz, 2019). However, studies have also reported that students' health-related physical activity knowledge is insufficient or inaccurate and that children's levels of physical activity are alarmingly low in many countries around the world (Aubert et al., 2018; Grasten et al., 2014; Keating et al., 2009; Placek et al., 2001; Sukys et al., 2019; Tremblay et al., 2014; Wilkie et al., 2016). Y1lmaz and Hünük (2018) observed in their study that students with a high level of health-related physical fitness knowledge did not acquire this knowledge from physical education teachers. The review of the available literature suggests that due to the inadequacy of physical education teachers' knowledge and skills on health-related physical fitness, they do not reflect these practices effectively in their 
physical education lessons. The fact that the Hünük et al. (2013) found that as physical education teachers' health-related physical fitness knowledge increased, so did their students' health-related physical fitness knowledge, shows that teachers play a key role in the results to be obtained in the applications of physical activity report cards. It has been determined that there are hardly any studies on this subject in the literature, especially in Turkey. For physical education teachers to create a learning environment in which health-related physical activity is encouraged in their classes, it is important to first identify the problems encountered in the learning environment. Therefore, this study aimed to determine whether physical education teachers' assessment of physical activity report card applications differs according to gender (female, male) and teaching experience (10 years or less, 11 years or more).

\section{METHODS}

\section{Study Groups}

Data were collected from physical education teachers working in the public lower secondary and upper secondary in 2019. A total of 91 physical education teachers, 33 females and 58 males, working in Adana and recruited by the convenience sampling method, participated in this study. Due to the difficulty of obtaining a random sample of participants, convenience sampling was used, and no prior sample size calculation was made (Fraenkel, Wallen, \& Hyun, 2012). The average age of the physical education teachers participating in the research was $36.96 \pm 5.75$, and the average years of teaching experience were $10.74 \pm 5.64$. Table 1 shows the means and standard deviations of age and years of teaching experience by gender.

\section{Data Collection Tools}

In the current study, the Physical Activity Report Card Applications Assessment Scale [PARCAAS] developed by Özgül et al. (2018) was used to reveal the views of physical education teachers on the practices of health-related physical activity reports cards. The scale consists of 38 items and 6 sub-scales assessing "Applicability", "Impact", "Difficulties", "Enforcement", "Competence", and "Support". Items 12, 18, and 27 on the scale are reverse scored. Each item was measured using a 5-point Likert-type scale ranging from 1 point for "Strongly disagree" to 5 "Strongly agree". The statements in the "Applicability" sub-dimension were prepared to reveal the the level of teachers' ability to apply the physical activity report cards (Sample item: I was able to apply physical activity report card measurements during class hours); in the "Impact" sub-dimension were prepared to reveal the impact level of their application (Sample item: I believe that physical activity report cards will be effective in 
combating obesity.); in the "Difficulties" sub-dimension were prepared to reveal the level of difficulty they experienced while performing the applications (Sample item: The time given was limited for the physical activity report card measurements and the transfer of the data to the system.); in the "Enforcement" sub-dimension were prepared to reveal the level of challenges they experienced during the practices (Sample item: In some physical activity report applications, students are reluctant. This reluctance makes the practice of physical education teachers difficult.); in the "Competence" sub-dimension were prepared to reveal the level of their ability to perform the activities (Sample item: Before applying the physical activity report card, I gave information to the students about the purpose and benefits of the measurements.); and the statements in the "Support" sub-dimension were prepared to reveal the level of support they received while doing the activities (Sample item: The school administration assisted in the providing the measuring instruments.). Scores for the subdimensions are between 12 and 60 for "Applicability", 9 and 45 for "Impact", 6 and 30 for "Difficulties", 3 and 15 for "Enforcement", 4 and 20 for "Competence", 4 and 20 for "Support". The high scores of physical education teachers in the sub-dimensions of "Applicability", "Impact", "Competence" and "Support" indicate that the physical activity report card applications are applicable and effective, that physical education teachers are competent in these practices, and that they are supported by the administrators and other teachers for the practices. The high scores obtained from the "Difficulties" and "Enforcement" sub-dimensions are evaluated as physical education teachers having difficulties and challenges in applying the physical activity report card applications. The Cronbach's alpha reliability coefficient obtained during the development of the scale was found to be .83 , and the reliability coefficient obtained within the scope of this study was found to be .83 , which was considered satisfactory for the study.

\section{Data Collection}

Teachers who participated in the study were conducted outside of their working hours and during their free time (outside working hours, recess, lunchtime), informed about the study. The data collection instruments were used following their consent to participate. Only physical education teachers who volunteered to participate were included in the study, and informed consent was obtained from each participant before the study began. It took approximately 10 minutes to complete the data collection instrument. According to the Declaration of Helsinki (World Medical Association, 2001). 
Table 1. Means and standard deviations of female and male teachers' age and years of teaching experience

\begin{tabular}{|c|c|c|c|c|}
\hline & \multicolumn{2}{|c|}{ Female $(n=33)$} & \multicolumn{2}{|c|}{ Male $(n=58)$} \\
\hline & \multicolumn{2}{|c|}{$\mathbf{n}$} & \multicolumn{2}{|c|}{$\mathbf{n}$} \\
\hline 10 years or fewer years of teaching experience & \multicolumn{2}{|c|}{21} & \multicolumn{2}{|c|}{28} \\
\hline \multirow[t]{2}{*}{11 years and more years of teaching experience } & \multicolumn{2}{|c|}{12} & \multicolumn{2}{|c|}{30} \\
\hline & $\bar{x}$ & SD & $\bar{x}$ & SD \\
\hline Age & 35.45 & 5.25 & 37.82 & 5.89 \\
\hline Years of Teaching Experience & 9.46 & 4.32 & 11.47 & 6.19 \\
\hline
\end{tabular}

Data Analysis

The statistical package IBM SPSS, version 20, was used to perform a quantitative analysis of the collected data. Descriptive analysis and a non-parametric test were used to analyze data, as the score was not normally distributed. The Mann-Whitney $U$ test was used to determine whether the scores obtained by female and male physical education teachers from sub-dimensions of the scale differ and whether the scores obtained from the scale's subdimensions differ according to years of teaching experiences of physical education teachers.

\section{RESULTS}

The Mann-Whitney $U$ test was applied to examine whether there is a statistically significant difference between the scores of male and female physical education teachers participating in the study on the subdimensions of the PARCAAS. The results of the analysis revealed that there is a statistically significant difference between the scores obtained from the sub-dimensions of "Enforcement" ( $U=645.50, p=.01)$, “Competence" $(U=635.50, p=.01)$ and "Support" $(U=630.00, p=.01)$. These findings revealed that female physical education teachers' scores on the sub-dimensions of "Enforcement" $(M d n$.female $=8.00, M d n$. male $=10.00)$, "Competence" $\left(M d n\right.$.female $=12.00, M d n$.male $\left._{\text {e }} 13.00\right)$, and "Support" $(M d n$.female $=13.00, M d n$. male $=15.00$ ) were lower than male physical education teachers. However, the results of the analysis revealed statistically no significant difference between the "Applicability" ( $U=758.50, p=.10)$, "Impact" $(U=920.00, p=.76)$, and “Difficulties" ( $U=772.00, p=.13)$ scores of male and female physical education teachers. These findings showed that the female and male physical education teachers' scores obtained from sub-scales of "Applicability" ( $M d n$.female $=44.00$, $M d n$.male $=47.36)$, “Impact" $(M d n$.female $=30.00, M d n$.male $=31.00)$ and "Difficulties" $(M d n$.female $=$ $19.00, M d n$. male $^{2} 22.00$ ) were similar. The mean, standard deviation, and median values of the sub-dimensions obtained by the male and female physical education teachers from PARCAAS are shown in Table 2. 
Table 2. Descriptive statistics (mean, standard deviation, median) of female and male teachers' PARCAAS scores

\begin{tabular}{ccccccc}
\hline & \multicolumn{3}{c}{ Female $(n=33)$} & \multicolumn{3}{c}{ Male $(n=58)$} \\
\hline Applicability & 44.44 & 5.64 & 44.00 & 46.35 & 4.90 & 47.36 \\
Impact & 30.74 & 4.13 & 30.00 & 30.76 & 4.32 & 31.00 \\
Difficulties & 18.99 & 4.30 & 19.00 & 20.41 & 4.39 & 22.00 \\
Enforcement & 8.15 & 2.37 & 8.00 & 9.67 & 2.56 & 10.00 \\
Competence & 11.32 & 3.57 & 12.00 & 13.36 & 2.95 & 13.00 \\
Support & 12.82 & 3.29 & 13.00 & 14.74 & 3.21 & 15.00 \\
\hline
\end{tabular}

The Mann-Whitney U test was applied to examine whether the scores obtained from the "Enforcement", "Competence" and "Support" sub-dimensions of female physical education differ according to the years of teaching experience of female physical education teachers. The teaching experience was calculated separately for male and female teachers since the scores they obtained from the sub-dimensions of "Enforcement", "Competence", and "Support" were different. The results of the analysis revealed statistically no significant difference obtained from the sub-dimensions of "Enforcement" $(U=103.50, p=.95)$, "Competence" $(U=99.50, p=.82)$, and "Support" $(U=104.00, p=.97)$ by female physical education teachers with 10 years or fewer and 11 years and more years of teaching experience. According to these findings, the scores obtained from the sub-dimensions of "Enforcement" $\left(\mathrm{Mdn}_{\text {.10yearsorless }}=8.00, \mathrm{Mdn} \cdot 11\right.$ yearsormore $\left.=9.06\right)$, “Competence" $(\mathrm{Mdn} \cdot 10 \mathrm{yearsorless}=12.00$, $\operatorname{Mdn} .11$ yearsormore $=12.31)$ and "Support" $\left(\mathrm{Mdn}_{\text {10yearsorless }}=12.00, \mathrm{Mdn}_{\text {11yearsormore }}=13.52\right)$ were similar for the female physical education teachers with 10 years or fewer experience and 11 years or more (Table 3).

The Mann-Whitney $U$ test was applied to examine whether the scores obtained from the "Enforcement", "Competence" and "Support" sub-dimensions of male physical education differ according to the years of teaching experience of male physical education teachers. The results of the analysis revealed statistically no significant difference between the score obtained from the sub-dimensions of "Enforcement" ( $U=294.00, p=.05)$, “Competence" (U = 387.00, $\mathrm{p}=.60)$, and "Support" ( $\mathrm{U}=414.00, \mathrm{p}=.93)$ by male physical education teachers with 10 years or fewer and 11 years and more years of teaching experience. According to these findings, it was observed that the scores obtained from the sub-dimensions of "Enforcement" $\left(\mathrm{Mdn}_{\cdot 10}\right.$ yearsorless $\left.=11.00, \mathrm{Mdn}_{\text {11yearsormore }}=9.06\right)$, “Competence" $(\mathrm{Mdn} \cdot 10 \mathrm{yearsorless}=13.50$, $\left.\operatorname{Mdn}_{\text {11yearsormore }}=13.00\right)$, and "Support" $\left(\mathrm{Mdn}_{\text {10yearsorless }}=15.00, \mathrm{Mdn}_{\text {11yearsormore }}=14.52\right)$ were 
similar for the male physical education teachers with 10 years or fewer experience and 11 years or more (Table 3).

Table 3. Descriptive statistics (mean, standard deviation, median) for teachers' PARCAAS scores by years of teaching experience

\begin{tabular}{|c|c|c|c|c|c|c|}
\hline & \multicolumn{6}{|c|}{ Female } \\
\hline & \multicolumn{6}{|c|}{ Years of Teaching Experience } \\
\hline & \multicolumn{3}{|c|}{10 years or fewer $(n=21)$} & \multicolumn{3}{|c|}{11 years or more $(n=12)$} \\
\hline & $x^{-}$ & $S D$ & $M d n$. & $x^{-}$ & $S D$ & $M d n$ \\
\hline Enforcement & 7.99 & 2.41 & 8.00 & 8.43 & 2.38 & 9.06 \\
\hline Competence & 11.03 & 3.17 & 12.00 & 11.82 & 4.27 & 12.31 \\
\hline \multirow[t]{5}{*}{ Support } & 12.72 & 3.48 & 12.00 & 13.01 & 3.05 & 13.52 \\
\hline & \multicolumn{6}{|c|}{ Male } \\
\hline & \multicolumn{6}{|c|}{ Years of Teaching Experience } \\
\hline & \multicolumn{3}{|c|}{10 years or fewer $(n=28)$} & \multicolumn{3}{|c|}{11 years or more $(n=30)$} \\
\hline & $\bar{x}$ & $S D$ & $M d n$ & $\bar{x}$ & $S D$ & $M d n$. \\
\hline Enforcement & 10.46 & 2.52 & 11.00 & 8.94 & 2.41 & 9.06 \\
\hline Competence & 13.52 & 3.22 & 13.50 & 13.21 & 2.72 & 13.00 \\
\hline Support & 14.61 & 3.59 & 15.00 & 14.86 & 2.86 & 14.52 \\
\hline
\end{tabular}

The Mann-Whitney $U$ test was applied to determine whether there was a statistically significant difference between the scores obtained from the "Applicability", "Impact", and "Difficulties" sub-dimensions of PARCAAS, which did not differ according to gender, according to the years of teaching experience. The results of the analysis showed that there was no statistically significant difference between physical education teachers with 10 years or fewer of teaching experience and 10 years or more in scores they obtained from the "Applicability" $(U=1002.50, p=.83)$, "Impact" $(U=1007.50, p=.86)$ and "Difficulties" $(U=$ $1015.00, p=.91$ ) sub-dimensions of PARCAAS. These findings showed that physical education teachers with 10 years or fewer of teaching experience and 11 years or more in terms of “Applicability" ( $U=1002.50, p=.83)$, "Impact" $(U=1007.50, p=.86)$, and “Difficulties" $(U=$ 1015.00, $p=.91$ ) sub-dimension scores were similar. These findings showed that physical education teachers with 10 years or fewer of teaching experience and 11 years or more in terms of "Applicability" (Mdn.10yearsorless $=47.00, M d n \cdot 11$ yearsormore $=46.00)$, “Impact" $(M d n$.10yearsorless $=$ 30.00, $M d n$.11yearsormore $=30.50)$, and “Difficulties" $(M d n$.10yearsorless $=20.00, M d n$.11yearsormore $=20.50)$ sub-dimension scores were similar (Table 4).

Table 4. Descriptive statistics (mean, standard deviation, median) for teachers' PARCAAS sub-dimensions scores by years of teaching experience

\begin{tabular}{|c|c|c|c|c|c|c|}
\hline & \multicolumn{6}{|c|}{ Years of Teaching Experience } \\
\hline & \multicolumn{3}{|c|}{10 years and fewer $(n=49)$} & \multicolumn{3}{|c|}{11 years and more $(n=42)$} \\
\hline & $x^{-}$ & $S D$ & $M d n$. & $\bar{x}^{-}$ & $S D$ & $M d n$. \\
\hline Applicability & 45.81 & 5.20 & 47.00 & 45.49 & 5.33 & 46.00 \\
\hline Impact & 30.82 & 4.59 & 30.00 & 30.68 & 3.81 & 30.50 \\
\hline Difficulties & 19.88 & 4.50 & 20.00 & 19.93 & 4.32 & 20.50 \\
\hline
\end{tabular}




\section{DISCUSSION}

It was found in the current study that physical education teachers' "Enforcement", "Competence" and "Support" sub-dimension scores differed according to gender, and the scores of female physical education teachers were lower than male physical education teachers. In physical education and sports, sportive activity, sportive performance, superior physical characteristics, talent, success, ambition, etc., are associated with men, and all these have a place in society as a male-specific activity. It is also emphasized that the gender-specific behaviors that society expects men and women to exhibit in childhood and are reinforced with educational life and gain legitimacy in social life (Aslan, 2015; Kağıtçıbaşı, 1981; Koca, 2006). All these reasons from the effect of traditional gender roles may have caused female physical education teachers to feel more inadequate in applying for physical activity report cards than male physical education teachers. Aydin (2019) found that the professional competencies of male physical education teachers were significantly higher than that of female physical education teachers in his study examining the professional competencies of physical education teachers. This supports the fact that male physical education teachers scored significantly higher than female teachers in the "Competence" sub-dimension.

On the other hand, although the scores of female physical education teachers in the "Competence" sub-dimension are relatively lower than male teachers and the level of both female and male physical education teachers was not at the expected level. In contrast, male and female physical education teachers are expected to score close to the maximum for the "Competence" sub-dimension. The fact that the knowledge levels of both female and male physical education teachers on health-related physical activity were found to be quite low in the studies carried out supports this finding (Castelli \& Williams, 2007; İnce \& Hünük, 2013; Santiago et al., 2009; Y1lmaz, 2019).

The fact that female physical education teachers scored lower than male teachers in the "Enforcement" sub-dimension indicates that women have less difficulty applying the physical activity report card applications than men. Studies have revealed that physical education teachers do not fully implement health-related physical education activities in their classes and spend more time on performance-oriented activities (Armour \& Harris, 2013; Cale et al., 2014; Castelli \& Williams, 2007; Y1lmaz, 2019). From this point of view, it is thought that the fact that male physical education teachers, who are influenced by traditional gender roles, are more focused on being strong or winning in their lessons causes them to have difficulty in applying health-related physical activity report cards that do not have these qualifications (Koca, 2006). 
Supporting the findings related to the "Support" sub-dimension obtained in this study, it has been determined in the studies conducted that school administrators and other branch teachers in the school do not care about physical education lessons, and school administrators do not support physical education teachers (Demirhan et al., 2014; Haerens et al., 2011; Ulucan et al., 2012). However, one of the reasons for the findings of male physical education teachers being relatively more supported than female physical education teachers may be that female physical education teachers have more problems with school administration than male teachers (Göktaş et al., 2011). In addition, the fact that school administrators see physical education teachers as teachers who provide discipline and safety at school and that they attribute this mission to male physical education teachers may have been effective in supporting male physical education teachers more (Demirhan et al., 2008; Mirzeoğlu et al., 2019).

It was determined that the scores obtained by physical education teachers from the sub-dimensions of "Applicability", "Impact" and "Difficulties" did not differ according to gender, and the scores of female and male physical education teachers were similar. It has also been determined that the scores of female and male physical education teachers in the "Applicability" sub-dimension are above the average and high. This finding shows that physical education teachers have positive views towards the applicability of the health-related physical activity report card. These positive views of physical education teachers can be explained by the fact that the health-related physical activity report card applications directed students to move. The increase in the physical activity of the students was reported, the students turned this situation into behavior and started to make conscious weight control (Salman \& Sar1, 2020; Salman et al., 2018).

It was determined that the scores of female and male physical education teachers in the sub-dimension of "Impact" did not differ and were above the average. This finding is in line with the results revealed in the literature that the application of the health-related physical activity report card increases the self-confidence of the students, encourages the students to move, makes the students aware of the physical activity related to health, makes the students healthy and happy, ensures that the students are directed to a sports branch, increases the prestige of the physical education lesson, provide data to physical education teachers about talent identification (Salman \& Sarı, 2020; Salman et al., 2018). In addition, students' use of health-related physical activity report card practices they experience at school in their daily lives and sharing this information with people around them is another indicator of the effectiveness of this practice (Y1lmaz, 2019). 
This study determined that the scores of female and male physical education teachers in the "Difficulties" sub-dimension of PARCAAS were above the average and similar. This finding shows that both female and male physical education teachers have difficulties applying for the health-related physical activity report card. The main reasons for these difficulties might be the measurement tools are not provided by the authorized institutions to the physical education teachers, the measurement material and measurement area in the schools is insufficient, the use of the lesson time for measurement and no extracurricular time is provided, the problems experienced in the process of transferring the measurements to the system, the exam-oriented students seeing the application unnecessary and their reluctance about measurements, and the high number of students in the classrooms (Demirhan et al., 2008; Demirhan et al., 2014; Salman \& Sar1, 2020; Salman et al., 2018).

The scores of physical education teachers in the sub-dimensions of "Applicability", "Impact", "Difficulties", "Enforcement", "Competence", and "Support" did not differ according to their years of teaching experience. The scores of teachers with fewer than 10 years and more than 10 years of teaching experience were similar. Teachers in both teaching experience groups had similar and above-average scores in the sub-dimensions of "Enforcement" and "Difficulties" indicates that teachers have difficulties and experience challenges in applying for the physical activity report card. This may be because physical education teachers stated that they had time, space, and material problems when measuring physical fitness, that they could not make the measurements following certain standards, and that some of the teachers and school administrators believed that this practice was not beneficial (Demirhan et al., 2014; Gülüm \& Bilir, 2011; Salman \& Sar1, 2020; Salman et al., 2018). Another factor that stimulates this situation may be that physical education teachers have insufficient health-related physical fitness knowledge and that although they know that they are unsuccessful in the implementation of health-related programs (Hünük et al., 2013; İnce \& Hünük, 2013; Santiago et al., 2016; Uğraş, 2018; Yllmaz, 2019) and get lack of sufficient support from the administrators to eliminate the deficiencies on the subject (Haerens et al., 2011). In addition, the lack of a standard in the measurements, the problems experienced in the process of entering the data into the system, the students not wanting to be measured in front of teachers of different genders, the unwillingness of thin or overweight students to have their measurements taken, the hygiene problem, the crowded classrooms, the uncontrollable behavior of other students while measuring a student, limited time for data entrance gives an idea about the result (Demirhan et al., 2014; Salman \& Sarl, 2020; Salman et al., 2018). Studies have shown that physical education teachers are directly affected by the attitudes and 
behaviors of experienced teachers in the teaching practice course they have taken during their university education (CoHE, 2018; İnce \& Ok, 2005). In this study, teachers with different teaching experiences had similar scores in the "Enforcement" and "Difficulties" subdimensions of the PARCAAS may have resulted from this situation.

In their study, Hill and Brodin (2004) stated that physical education teachers had difficulties planning the lesson and classroom management in the first years of their profession. These problems stemmed from the physical and the social structure of the school. The views of teachers with fewer years of teaching experience on the implementation of health-related physical activity report cards may have been affected by this situation. According to the physical education curriculum reconsidered with a constructivist approach, physical education teachers are expected to plan and implement the lesson student-centered (MoNE, 2007). Although it is emphasized that in learning environments prepared under the constructivist approach, the student should participate in learning activities by doing and experiencing, not be dependent on the teacher for learning and that the teacher should carry out the activities by using student-centered styles planned under the content of the lesson (İnce \& Hünük; 2010; MoNE, 2007; Saraç \& Muştu, 2013), the researches carried out showed that physical education teachers use teacher-centered teaching approaches, devote a significant part of their lessons to the administrative activities and keep students mostly inactive during physical education classes, regardless of their professional experience (Hasty, 1997; Parker \& Curtner-Smith, 2012; Parsak \& Saraç, 2019; Saraç, 2003; SueSee \& Edwards, 2011). Within the scope of the implementation of the health-related physical activity report card, physical education teachers with 10 years or fewer teaching experience and 11 years or more have followed a teacher-centered path and devoted a significant part of the lesson to administrative activities, while the other students in the class are standing still or undisciplined while measuring a single student and these problems might have made the implementation of health-related physical activity report card difficult (Ünlü \& Aydos, 2008).

The "Support" sub-dimension showed that teachers with 10 years or fewer of experience and 11 years or more of teaching experience scored above the average and high. This situation reveals that physical education teachers are supported by the administrators and teachers in other branches in their schools in terms of supplying materials, providing a practice area, and their belief in the necessity of applying physical activity card applications. It is thought that the fact that school administrators and other field teachers in the school see physical education teachers as teachers who provide discipline and safety at school may have affected the support they give to physical education teachers (Demirhan et al., 2008). 
In the sub-dimension of "Competence", it was observed that teachers with 10 years or fewer and 11 years or more teaching experience got an average score. It is thought-provoking that physical education teachers got a score close to the average, while teachers are expected to get close to the maximum score from this subdimension, based on the fact that they play a key role in students' acquisition of lifelong physical activity participation, and this dimension, which consists of information that overlaps with the field of physical education. Previously published findings show that the physical education teachers' level of health-related physical activity knowledge is low (Castelli \& Williams, 2007; İnce \& Hünük, 2013; Santiago et al., 2009; Yllmaz, 2019). While physical education teachers attribute their low proficiency on this subject to their insufficient English language knowledge and limited access to relevant articles; Researchers emphasize that this is because health-based lessons are challenging, physical education teachers do not prepare enough for health-based physical education lessons, and they want to teach physical education lesson more performance-oriented (Armour, 2010; Armour \& Harris, 2013; Cale et al., 2014; Y1lmaz, 2019). All these reasons may be the reason why teachers' proficiency is not very high.

In the sub-dimensions of "Applicability" and "Impact", it was determined that teachers with 10 years or fewer and 11 years or more of teaching experience scored above the average. According to physical education teachers, it can be said that the applicability and effect of physical activity report cards are relatively high. It can be said that physical education teachers think that the applicability and effect of physical activity report cards are relatively high. In recent years, the increasing concern about the low level of physical activity of children and youth and the increase in the number of obese students due to inactivity has made the role of physical education in promoting health more prominent (Cale et al., 2014). Physical education teachers are expected to contribute to public health by promoting healthy living habits of individuals in society and increasing physical activity. Based on all this information, it can be interpreted that physical education teachers think that their students' physical activity levels can be increased through health-related physical activity report card applications and develop healthy living habits in students with these applications.

\section{CONCLUSIONS}

The results of the research showed that the scores for the sub-dimensions of "Enforcement", "Competence" and "Support" differ between male and female physical education teachers; however, the scores for the sub-dimensions of "Applicability", "Impact" and "Difficulties" did not differ between male and female physical education teachers. It was 
also determined that male physical education teachers had more difficulties during the healthrelated physical activity report card applications than females. Female teachers considered themselves less competent, and female teachers received less support from school administrators than men in health-related physical activity report card applications. It was found that both male and female physical education teachers had similar views on the "Applicability", "Impact," and "Difficulties" sub-dimensions and concluded that they had difficulties during the health-related physical activity report card applications but thought that the scale was applicable and effective. It was also concluded that physical education teachers with teaching experience of 10 years or fewer and 11 years or more had difficulties in report card applications, regarded themselves as moderately competent, received sufficient support from school administrators, and thought that the activity was applicable and effective. The relatively small number of participants in this study is one of the study's limitations. Despite this, the fact that there are almost no studies on the subject in the literature and the determination of the problems faced by physical education teachers in the application of the scale in this study is the strength of this research. The results of this research revealed the functioning and failing sides of the health-related physical activity report card applications implemented by the MoNE to increase students' awareness of physical activity and to encourage physical activity participation of students. School principals and physical education teachers taking responsibility for the implementation of the health-related physical activity report card applications put into practice by the MoNE will undoubtedly play an important role in making the students habit of physical activity for a healthy life.

\section{Practical Implications}

In order for physical education teachers to carry out the health-related physical activity report card applications in accordance with their purpose, the school administrators should be provided with resources, and MoNE should hold informative meetings on these issues in terms of providing the necessary materials, providing the appropriate space and making the practices carefully. Also, physical education and all field teachers should be provided with necessary training and practices at the national level to instill that one of the prerequisites for society to be healthy throughout life is to be physically active. It is thought that planning inschool and out-of-school activities will be effective so that participation in physical activity for lifelong health becomes a habit in students. In matters where physical education teachers do not consider themselves competent, local level National Education administrators can cooperate with universities to eliminate the deficiencies of teachers in related subjects. To 
ensure the active participation of the students in the practices, it is recommended that the places where the measurement is made are hygienic, that the teachers should avoid statements that will damage the self-confidence of the students who are measured during the measurements of the very thin or overweight students and practices in which the whole class will be active to prevent the undisciplined behavior of the students during the measurement. In the light of the findings obtained, it is recommended that physical fitness and health-based pedagogical lessons, courses, and seminars are provided to physical education teacher candidates and in-service teachers. Moreover, for physical education teachers to be able to implement health-related physical activity report card applications successfully, the time can be extended to a wider period to reduce problems in the practices, materials, and equipment should be provided by authorized institutions. Necessary support should be provided for teachers to enter the collected data of health-related physical activity report card. It is recommended that future research should examine health-related physical activity report card practices from the eyes of students or school administrators, compare secondary and high school teachers' views on health-related physical activity report card practices, and study health-related physical activity report card practices with a larger sample of physical education teachers.

\section{Authors' contributions}

Two authors conceived the study idea and designed the methodology of the study. The data were collected by the first author and analyzed and interpreted by the corresponding author. Both authors reviewed the results, drafted the manuscript, and approved the final version of the manuscript.

\section{Declaration of conflict interest}

The authors have no relevant financial or non-financial competing interests to declare in relation to this manuscript.

\section{REFERENCES}

Altunkaynak, B. Z., \& Özbek, E. (2006). Obezite: Nedenleri ve tedavi seçenekleri. Van Tıp Dergisi, 13(4), 138-142.

Armour, K. M. (2010). The physical education profession and its professional responsibility... or... why '12 weeks paid holiday' will never be enough. Physical Education and Sport Pedagogy, 15(1), 1-13. doi.org/10.1080/17408980903413479

Armour, K., \& Harris, J. (2013). Making the case for developing new PE-for-health pedagogies. Quest, 65(2), 201-219. doi.org/10.1080/00336297.2013.773531 
Aslan, G. (2015). A metaphoric analysis regarding gender perceptions of preservice teachers. Education and Science, 40(181). doi:10.15390/EB.2015.2930

Aubert, S., Barnes, J. D., Abdeta, C., Abi Nader, P., Adeniyi, A. F., Aguilar-Farias, N., ... \& Tremblay, M. S. (2018). Global matrix 3.0 physical activity report card grades for children and youth: Results and analysis from 49 countries. Journal of Physical Activity and Health, 15(s2), S251-S273. doi: 10.1123/jpah.2018-0472.

Aydın, E. (2019). Investigation of the vocational proficiency of physical education teachers in terms of different variables. Gaziantep University Journal of Sport Sciences, 4(3), 411-425. doi: $10.31680 /$ gaunjss.623361

Biddle, S. J., Gorely, T., Marshall, S. J., Murdey, I., \& Cameron, N. (2004). Physical activity and sedentary behaviours in youth: Issues and controversies. The Journal of the Royal Society for the Promotion of Health, 124(1), 29-33. doi.org/10.1177\%2F146642400312400110

Bulut, S. (2013). A social determinant of health, physical activity. Turkish Bulletin of Hygiene $\mathcal{E}$ Experimental Biology/Türk Hijyen ve Deneysel Biyoloji,70(4), 205-214. doi: $\underline{10.5505 / T u r k H i j y e n .2013 .67442}$

Cale, L., Harris, J., \& Chen, M. H. (2014). Monitoring health, activity and fitness in physical education: Its current and future state of health. Sport, Education, and Society, 19(4), 376397. doi.org/10.1080/13573322.2012.681298

Castelli, D., \& Williams, L. (2007). Health-related fitness and physical education teachers' content knowledge. Journal of Teaching in Physical Education, 26(1), 3-19. doi.org/10.1123/itpe.26.1.3

Cecchini, M., Sassi, F., Lauer, J. A., Lee, Y. Y., Guajardo-Barron, V., \& Chisholm, D. (2010). Tackling of unhealthy diets, physical inactivity, and obesity: Health effects and costeffectiveness. The Lancet, 376(9754), 1775-1784. doi.org/10.1016/S0140-6736(10)61514-0

Coşkun Özyol, F., \& Asma, M. B., (2020). Adölesanlarda obezite risk faktörleri ve tedavisi. Sporda Akademik Yaklaşımlar-3 (pp.55-62), Gece Kitaplığı.

Council of Higher Education (2018). Beden eğitimi ve spor öğretmenliği lisans programi. Retrieved July 3, 2021, from: https://www.yok.gov.tr/Documents/Kurumsal/egitim_ogretim_dairesi/YeniOgretmen-Yetistirme-Lisans-

Programlari/Beden_Egitimi_ve_Spor_Ogretmenligi_Lisans_Programi.pdf

Demirhan, G., Bulca, Y., Altay, F., Şahin, R., Güvenç, A., Aslan, A., ... \& Açıkada, C. (2008). Beden eğitimi öğretim programları ve programların yürütülmesine ilişkin paydaş görüşlerinin karşılaştırılması. Spor Bilimleri Dergisi, 19(3), 157-180.

Demirhan, G., Bulca, Y., Saçlı, F., \& Kangalgil, M. (2014). Beden eğitimi öğretmenlerinin uygulamada karşılaştıkları sorunlar ve çözüm önerileri. Hacettepe Üniversitesi Eğitim Fakültesi Dergisi, 29(29-2), 57-68.

Doolan, M. (2012). Development and trial of a report card on children's physical activity in Western Australia (Unpublished master's thesis). University of Notre Dame Australia, Australia.

Edginton, C. R., Mingkai, C., \& Demirhan, G. (2010). Beden eğitimi ve sağlik: Yeni bir küresel görüş birliği. Spor Bilimleri Dergisi, 21(3), 122-128.

Erdoğan, M., Certel, Z., \& Güvenç, A. (2011). Masa başı çalışanlarda fiziksel aktivite düzeyi: Obezite ve diğer özelliklere göre incelenmesi (Akdeniz Üniversitesi Tıp Fakültesi Hastanesi Örneği). Spor Hekimliği Dergisi, 46(3), 097-107. 
Fraenkel, J. R., Wallen, N. E., \& Hyun, H. H. (2012). How to design and evaluate research in education. New York: McGraw-Hill.

Göktaş, Z., Özmaden, M., \& Yetim, A. A. (2011). Beden eğitimi öğretmenlerinin meslekte karşılaştıkları sorunlar (Balıkesir ili uygulaması). Selçuk Üniversitesi Beden Eğitimi ve Spor Bilim Dergisi, 13 (1), 112-118

Gråstén, A., Jaakkola, T., Liukkonen, J., \& Tammelin, T. (2014). Finnish report card 2014 on physical activity for children and youth. Retrieved July 3, 2021, from https://jyx.jyu.fi/bitstream/handle/123456789/44282/1/978-951-39-5699-8.pdf

Gülüm, V., \& Bilir, P. (2011). Beden eğitimi öğretim programının uygulanabilme koşulları ile ilgili beden eğitimi öğretmenlerinin görüşleri. Spormetre Beden Eğitimi ve Spor Bilimleri Dergisi, 9(2), 57-64.

Hacettepe University Faculty of Medicine (2017). Ulusal hastalık yükü çalışması sonuçları ve çözüm önerileri. Retrieved July 3, 2021, from https://tip.hacettepe.edu.tr/ekler/pdf/ulusal_program.pdf

Haerens, L., Kirk, D., Cardon, G., \& De Bourdeaudhuij, I. (2011). Toward the development of a pedagogical model for health-based physical education. Quest, 63(3), 321-338. doi.org/10.1080/00336297.2011.10483684

Han, J. C., Lawlor, D. A., \& Kimm, S. Y. (2010). Childhood obesity. The Lancet, 375(9727), 17371748. doi.org/10.1016/S0140-6736(10)60171-7

Hasty, D. L. (1997). The impact of British national curriculum physical education on teachers' use of teaching styles: A case study in one English town (Unpublished Doctoral Dissertation). University Of Alabama, Tuscaloosa, Ala., USA.

Hill, G., \& Brodin, K. L. (2004). Physical education teachers' perceptions of the adequacy of university coursework in preparation for teaching. Physical Educator, 61(2), 75.

Hünük, D., Ince, M. L., \& Tannehill, D. (2013). Developing teachers' health-related fitness knowledge through a community of practice: Impact on student learning. European Physical Education Review, 19(1), 3-20. doi.org/10.1177\%2F1356336X12450769

İnce, M. L. ve Ok, A. (2005). Moving prospective physical education teachers to learnercentered teaching: Can it be stimulated in a traditional context. Journal of International Council for Health, Physical Education, Sport and Dance, 41(1), 6-12. https://hdl.handle.net/11511/81237

İnce, M. L., \& Hünük, D. (2010). Eğitim reformu sürecinde deneyimli beden eğitimi öğretmenlerinin kullandıkları öğretim stilleri ve stillere ilişkin algıları. Eğitim ve Bilim, 35(157), 128-139.

İnce, M. L., \& Hünük, D. (2013). Deneyimli beden eğitimi öğretmenlerinin sağlıkla ilgili fiziksel uygunluk bilgi düzeyleri ve bilgi içselleştirme süreçleri. Eğitim ve Bilim, 38(168), 304317.

Kağıtçıbaşı, Ç. (1981). Çocuğun değeri: Türkiye'de değerler ve doğurganlık. Boğaziçi Üniversitesi, İdari Bilimler Fakültesi.

Kann, L., McManus, T., Harris, W. A., Shanklin, S. L., Flint, K. H., Hawkins, J., ... \& Zaza, S.

(2016). Youth risk behavior surveillance - the United States, 2015. Morbidity and Mortality

Weekly Report: Surveillance Summaries, 65(6), 1-174. https://www.jstor.org/stable/24805802

Keating, X. D., Harrison, L., Chen, L., Xiang, P., Lambdin, D., Dauenhauer, B., ... \& Piñero, J. C. (2009). An analysis of research on student health-related fitness knowledge in K-16 
physical education programs. Journal of Teaching in Physical Education, 28(3), 333-349. doi.org/10.1123/itpe.28.3.333

Koca, C. (2006). Beden eğitimi ve spor alanında toplumsal cinsiyet ilişkileri. Spor Bilimleri Dergisi, 17(2), 81-99.

Lonsdale, C., Rosenkranz, R. R., Peralta, L. R., Bennie, A., Fahey, P., \& Lubans, D. R. (2013). A systematic review and meta-analysis of interventions designed to increase moderateto-vigorous physical activity in school physical education lessons. Preventive Medicine, 56(2), 152-161. doi.org/10.1016/j.ypmed.2012.12.004

Ministry of National Education (2007). Beden eğitimi dersi (1-8. Sinıflar) öğretim programı ve kılavuzu. Devlet Kitapları Müdürlüğü.

Ministry of National Education (2018). Öğrencilerin Fiziksel Uygunluk Karnesi Açılandı. Retrieved July 3, 2021, from http:/ / www.meb.gov.tr/ogrencilerin-fiziksel-uygunlukkarnesi-aciklandi/haber/17402/tr

Ministry of National Health (2014). Türkiye fiziksel aktivite rehberi (940).Kuban Matbaacıllk Yayıncilik.

Ministry of National Health (2019a). Türkiye beslenme ve sağlık araştırması (1132). Tiraj Basım ve Yayın Sanayi Ticaret LTD. ŞTİ.

Ministry of National Health (2019b). Çocukluk çă̆ı obezitesinin önlenmesi ile ilgili eylem planı 2019-2023. Retrieved December 5, 2021, from https://hsgm.saglik.gov.tr/depo/birimler/saglikli-beslenme-hareketli-hayat-

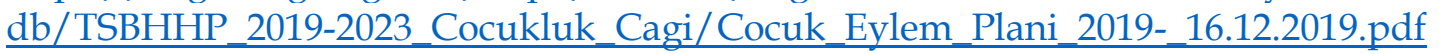

Ministry of National Health/Ministry of National Education (2017). Beden eğitimi öğretmenleri için sağlıkla ilgili fiziksel uygunluk karnesi uygulama rehberi.

Mirzeoğlu, A. D., Yaralı, S. S., Çoknaz, D., \& Özmen, S. (2019). Beden eğitimi ve spor öğretmenlerinin gözünden dersleri ve meslekleri (Sakarya Örneği). Gazi Beden Eğitimi ve Spor Bilimleri Dergisi, 24(2), 111-131.

Özgül, F., Kangalgil, M., Çali, O., \& Yildiz, R. (2018). Investigation of physical activity report card applications by physical education and sports teachers. Journal of Education and Training Studies, 6(8), 44-51. doi.org/10.11114/jets.v6i8.3217

Parker, M., \& Curtner-Smith, M. (2012). Preservice teachers' use of production and reproduction teaching styles within multi-activity and sport education units. European Physical Education Review, 18(1), 127-143. doi.org/10.1177\%2F1356336X11430655

Parsak, B., \& Saraç, L. (2019). Turkish physical education teachers' use of teaching styles: Selfreported versus observed. Journal of Teaching in Physical Education, 39(2), 137-146. doi.org/10.1123/itpe.2018-0320

Placek, J. A., Griffin, L. L., Dodds, P., Raymond, C., Tremino, F., \& James, A. (2001). Middle school students' conceptions of fitness: The long road to a healthy lifestyle. Journal of Teaching in Physical Education. 20, 314-323.

Salman, U., \& Sarı, İ. (2020). Beden eğitimi öğretmenleri, öğrenciler ve ailelerin bakış açısı ile sağlikla ilgili fiziksel uygunluk karnesi: Yeni bir uygulama. SPORMETRE Beden Eğitimi ve Spor Bilimleri Dergisi, 18(2), 77-103. doi.org/10.33689/spormetre.589153

Salman, U., Sarı, İ., \& Mirzeoğlu, A. D. (2018). Beden eğitimi öğretmenleri gözüyle sağlıkla ilgili fiziksel uygunluk karnesi. İönü Üniversitesi Beden Eğitimi ve Spor Bilimleri Dergisi, 5(3), 1-24. 
Santiago, J. A., Morales, J., \& Disch, J. G. (2009). Physical activity and health-related fitness knowledge of physical education teachers. Research Quarterly for Exercise and Sport, 80(1), A72-A73.

Santiago, J. A., Morales, J., Disch, J. G., \& Morrow Jr, J. R. (2016). Preservice physical education teachers' content knowledge of physical activity and health-related fitness. The IchperSd Journal of Research, 44(1), 86-100.

Saraç, L. (2003). Teaching effectiveness indices of in-service and prospective physical education teachers (Masters Thesis). METU, Ankara.

Saraç, L., \& Muştu, E. (2013). Öğretmen adaylarının beden eğitimi öğretim stillerini kullanım düzeyleri ile stillere ilişkin değer algılarının incelenmesi. Pamukkale Journal of Sport Sciences, 4(2), 112-124.

SueSee, B. ve Edwards, K. (2011). Self-identified and observed teaching styles of senior physical education teachers in Queensland schools. In Proceedings of the 27th Australian Council for Health, Physical Education and Recreation Conference (ACHPER 2011) (pp. 208219). Australian Council for Health Physical Education and Recreation (ACHPER). http://www.achper.org.au/documents/item/83

Sukys, S., Emeljanovas, A., Gruodyte-Raciene, R., Mieziene, B., Trinkuniene, L., Rutkauskaite, R., \& Tremblay, M. (2019). Results from Lithuania's 2018 report card on physical activity for children and youth. International Journal of Environmental Research and Public Health, 16(23), 4710. doi.org/10.3390/ijerph16234710

Tremblay, M. S., Barnes, J. D., \& Bonne, J. C. (2014). Impact of the active healthy kids Canada report card: A 10-year analysis. Journal of Physical Activity and Health, 11(s1), S3-S20. doi.org/10.1123/jpah.2014-0167

Turkish Society of Endocrinology and Metabolism (2018). Obezite tanı ve tedavi kılavuzu. Ankara: Miki Matbaacılık San. ve Tic. Ltd. Şti.

Uğraş, S. (2018). Beden eğitimi öğretmenleri kendilerini hangi konularda yetersiz hissediyor?. Çanakkale Onsekiz Mart Üniversitesi Spor Bilimleri Dergisi, 1(1), 1-16.

Ulucan, H., Türkçapar, Ü., \& Cihan, B. (2012). Beden eğitimi öğretmenlerinin meslekte karşılaştıkları sorunların incelenmesi Kırşehir ili uygulaması. Ahi Evran Üniversitesi Kırşehir Eğitim Fakültesi Dergisi, 13(2), 265-277.

Ünlü, H., \& Aydos, L. (2008). Beden eğitimi dersinde sınıf yönetimi. Uluslararası İnsan Bilimleri Dergisi, 5(1), 1-7.

Wilkie, H., Standage, M., Sherar, L., Cumming, S., Parnell, C., Davis, A., ... \& Jago, R. (2016). Results from England's 2016 report card on physical activity for children and youth. Journal of Physical Activity and Health, 13(s2), S143-S149. doi.org/10.1123/jpah.2016-0298

World Health Organization. (2010). Framework for the implementation of the global strategy on diet, physical activity and health in the Eastern Mediterranean Region: Working document (No. WHO-EM/HLP/045/E/03.10/50). Retrieved July 3, 2021, from https://applications.emro.who.int/dsaf/emropub_2010_1273.pdf

World Health Organization. (2018). Global action plan on physical activity 2018-2030: More active people for a healthier world. Retrieved July 3, 2021, from https:/ /apps.who.int/iris/bitstream/handle/10665/272722/9789241514187eng.pdf?sequence $=1 \&$ isAllowed $=y$ 
World Health Organization. (2021). Obesity and Overweight. Retrieved July 3, 2021, from https://www.who.int/news-room/fact-sheets/detail/obesity-and-overweight

World Medical Association. (2001). World medical association declaration of Helsinki. Ethical principles for medical research involving human subjects. Bulletin of the World Health Organization, 79(4), 373.

Yılmaz, E. B. ve Hünük, D. (2018) Ortaokul öğrencilerinin sağlıkla ilgili fiziksel uygunluk bilgilerinin ve fiziksel aktivite düzeylerinin incelenmesi, 13.Uluslararas1 FIEP Avrupa Kongresi ve 29. Dünya Kongresi, 26-28 Eylül, Marmara Üniversitesi, İstanbul.

Y1lmaz, E. B., (2019). Beden eğitimi öğretmenlerinin sağlıkla ilgili fiziksel uygunluk bilgisini ders uygulamalarına aktarma süreçlerinin öğretmen ve öğrenci gözüyle incelenmesi (Yayınlanmamış yüksek lisans tezi). Pamukkale Üniversitesi, Denizli. 